\title{
Analisis Jumlah dan Sudut Blade terhadap Kecepatan dan Tekanan Turbin Air Savonius dengan Metode CFD
}

\author{
Doddy Suanggana $^{1, \mathrm{a})}$, Faisal Manta ${ }^{2, \mathrm{~b})}$ dan Gilang Ramadhan ${ }^{3, \mathrm{c})}$ \\ 1,2,3Program Studi Teknik Mesin Institut Teknologi Kalimantan \\ Jl. Soekarno Hatta No.KM 15, Karang Joang, Kec. Balikpapan Utara, Kota Balikpapan, Kalimantan Timur 76127 \\ a) doddy.suanggana@ lecturer.itk.ac.id, b) faisal86@lecturer.itk.ac.id, ${ }^{c)} 03171027 @$ student.itk.ac.id
}

\begin{abstract}
Abstrak
Salah satu sumber energi yang dapat menghasilkan listrik ramah lingkungan adalah tenaga air. Turbin air memiliki berbagai macam tipe yang digunakan sesuai dengan keadaan aliran air. Turbin tipe savonius digunakan untuk mengembangkan sumber energi air ini, yang memiliki daerah aliran sempit dan kecepatan aliran air rendah. Salah satu jenis turbin tersebut adalah turbin savonius, yang utamanya digunakan untuk memanfaatkan energi angin untuk kemudian diaplikasikan pada pembuatan turbin air. Penelitian ini bertujuan untuk mengetahui nilai dan pengaruh dari jumlah dan sudut blade pada distribusi tekanan dan kecepatan pada turbin. Penelitian dilakukan dengan membuat model dan menggunakan software simulasi Solidworks Flow Simulation 2020. Pada distribusi kecepatan, rata-rata paling tinggi terjadi pada turbin 2 sudu dengan sudut blade $135^{\circ}$ yaitu $1,437 \mathrm{~m} / \mathrm{s}$. Sedangkan yang paling rendah terjadi pada turbin 4 sudu dengan sudut blade $90^{\circ}$ yaitu $1,420 \mathrm{~m} / \mathrm{s}$. Pada turbin 2 sudu dengan sudut blade $135^{\circ}$ memberikan perbedaan distribusi rata-rata tekanan paling tinggi yaitu $101.338,74 \mathrm{~Pa}$, sedangkan turbin dengan jumlah 4 sudu dengan sudut blade $135^{\circ}$ memberikan perbedaan distribusi rata-rata tekanan paling rendah yaitu 101.333,21 Pa.
\end{abstract}

Kata kunci: kecepatan, sudu, tekanan, turbin air

\begin{abstract}
One of the energy sources that can produce electricity environmentally friendly is hydropower. Water turbines have various types according to the conditions of the water flow. Type of the savonius turbine is used to develop this water energy source, which has a narrow flow area and low water flow velocity. One type of turbine is the savonius turbine, which is mainly used to utilize wind energy then applied to the construction of a water turbine. This study aims to determine the value and effect of the number and angle of the blades with pressure and velocity distribution of the turbine. The research was conducted by making models and using the Solidworks Flow Simulation 2020. In the velocity distribution, the highest average occurs in a 2-blade turbine with a blade angle of $135^{\circ}$ that is $1.437 \mathrm{~m} / \mathrm{s}$. While the lowest occurs in a 4-blade turbine with a blade angle of $90^{\circ}$ which is $1.420 \mathrm{~m} / \mathrm{s}$. In a 2-blade turbine with $135^{\circ}$ angle, the difference in the average distribution of the highest pressure is 101,338.74 Pa, while the turbine with a 4 blade of $135^{\circ}$ angle gives the difference in the lowest average pressure distribution with 101,333.21 Pa.
\end{abstract}

Keywords: blade, pressure, velocity, water turbine

\section{PENDAHULUAN}

Masalah lingkungan seperti yang dicirikan oleh pemanasan global menjadi masalah dalam beberapa tahun terakhir. Jelas bahwa menggunakan energi alam secara efektif mengarah pada pencapaian energi berkelanjutan. Tenaga air harus menjadi perhatian sistem pembangkit tenaga listrik karena merupakan sumber energi yang ramah lingkungan dan terbarukan dengan kepadatan tertinggi, bekerja sama dengan tenaga angin dan matahari. Sebagian besar tenaga air dihasilkan oleh pembangkit listrik tenaga air dengan skala besar. Beberapa orang berpendapat bahwa pembangunan bendungan dapat menyebabkan kerusakan lingkungan yang luar biasa. Turbin arus air menghasilkan listrik dengan menggunakan energi kinetik sumber daya air alam menggunakan berbagai jenis rotor. Rotor ini biasa dipasang pada struktur di tepi sungai atau di struktur yang mengapung [1]. Turbin hidrolik dapat mengubah energi air menjadi energi listrik. Ada berbagai macam jenis turbin air yang sesuai digunakan dalam kondisi aliran fluidanya. Turbin Savonius menjadi salah satu pilihan jenis turbin yang hakikatnya dipakai untuk pemanfaatan energi angin yang kemudian digunakan dalam pengolahan turbin/kincir air. Turbin angin sumbu vertikal atau biasa disebut dengan turbin angin Savonius ditemukan pada tahun 1922 oleh insinyur asal Finlandia, Sigurd Savonius. Karena luas permukaan bilah yang besar, turbin dapat digunakan di bawah aliran air yang rendah yang dapat mengolah sebagian besar aliran air dan memberikan putaran yang besar. Ketika rotor dapat berputar secara otomatis ketika 
air mengenai sudu-sudu turbin juga dapat menerima aliran air pada sudu-sudu dari berbagai arah. Ukuran dan komposisi yang sederhana adalah keunggulan lain dari turbin savonius [2]. Di zaman modern ini, perkembangan teknologi yang pesat telah menyebabkan peningkatan kebutuhan energi listrik. Permintaan energi, terutama listrik akan sulit untuk dikurangi. Oleh karena itu, penggunaan energi listrik yang ramah lingkungan menjadi pilihan dan prioritas. Menurut hasil proyeksi dalam draft Rencana Umum Ketenagalistrikan Nasional (RUKN) 2012-2031, diperkirakan kebutuhan listrik Indonesia akan meningkat rata-rata $10,1 \%$ per tahun. Sehingga energi harus dikembangkan untuk penggunaan pembangkit. Sumber daya listrik Indonesia masih menggunakan bahan bakar fosil, karena kebutuhan listrik yang terus meningkat, semakin sedikit menggunakan bahan bakar fosil sebagai bahan bakar pembangkit listrik [3].

Proses pembuatan dan aplikasi turbin Savonius sebagai unit tenaga listrik harus dilakukan dengan benar dan efektif. Untuk menghasilkan turbin air yang berkualitas maka perlu dilakukan pengujian rotor pada turbin yang merupakan komponen utama turbin savonius untuk memenuhi kebutuhan listrik Indonesia. Oleh karena itu, penelitian ini membahas pengaruh jumlah dan sudut blade terhadap distribusi kecepatan dan tekanan pada model turbin Savonius.

\section{LANDASAN TEORI}

\section{A. Turbin Savonius}

Turbin Savonius adalah turbin sumbu vertikal yang pada dasarnya beroperasi karena gaya seret fluida pada sudu turbin, tetapi gaya angkat juga berkontribusi terhadap daya mekanis yang ditransmisikan ke poros. Turbin Savonius ditemukan oleh ilmuwan Savonius di Finlandia pada tahun 1928. Turbin ini adalah tipe resistansi yang profil sudunya adalah setengah lingkaran. Tekanan yang berbeda di kedua sisi bilah dan torsi yang berbeda di antara sudu mendorong turbin untuk berputar [4]. Pada Gambar 1 menunjukkan struktur turbin Savonius.

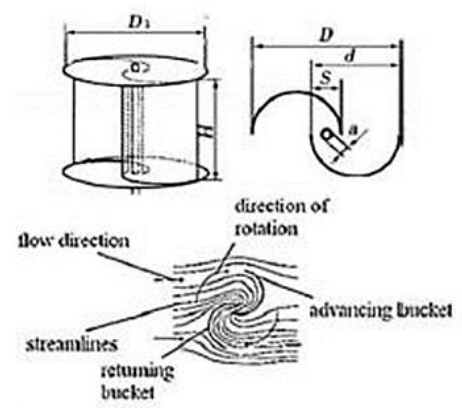

Gambar 1. Struktur turbin rotor savonius

Pada Gambar 2, turbin yang ditunjukkan berputar ke arah fluida dengan kecepatan turbulen $V_{0}$, dan kecepatan rotasinya diwakili oleh $\omega$. Ketika rotor bergerak di sepanjang lintasannya dan berputar di sepanjang sudut posisi tertentu, mereka menunjukkan profil fluida yang berbeda, sehingga secara berkala mengubah koefisien hambatan dan koefisien lift. Oleh karena itu, selama perputaran perangkat, torsi yang dihasilkan oleh rotor secara berkala berubah dengan konstanta $\omega[5]$.

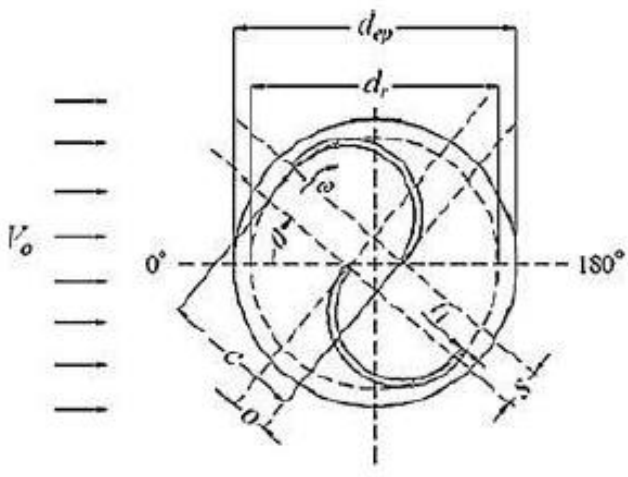

Gambar 2. Karakteristik turbin savonius

Jenis aliran ditunjukkan pada Gambar 2.6. Aliran (I) menghasilkan gaya angkat, (II) dan (III) tekanan balik ke permukaan cekung sudu, dan (IV) mempengaruhi daya rotor. Aliran tambahan yang diamati (I) hingga $45^{\circ}$. Aliran yang melekat ini (I) menjadi aliran resistansi (II) menuju sisi cekung dari sudu balik. Aliran pertama memberikan daya angkat, sedangkan aliran terakhir memulihkan tekanan pada permukaan cekung bilah, yang keduanya berkontribusi pada peningkatan koefisien daya rata-rata. Vortex shedding dari ujung blade terdepan (V) sama dengan $90^{\circ}$. Sebuah pusaran pembuangan dihasilkan dari ujung balik rotor (VI). Ketika lebih besar dari $90^{\circ}$, pusaran pembuangan $(\mathrm{V})$ terpisah dari ujung depan ember dan meningkat dengan aliran hilir rotor. Laju aliran yang ditandai dengan (IV), (V) dan (VI) pada Gambar 2.6 membantu mengurangi kekuatan rotor [5].
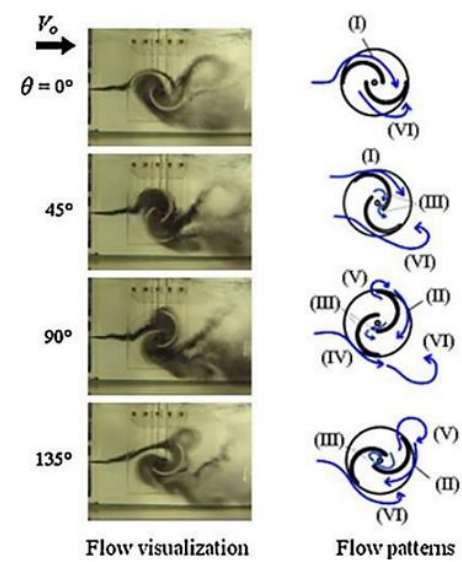

(I) Coand-like flow
(II) Dragging flow
(II) Overlap flow
(IV) Stagnation flow
(v) Vortex from advancing blade
(V) Vortex from retuming blade

Gambar 3. Pola Aliran pada rotor savonius

\section{B. Sudu Turbin}

Sudu adalah suatu komponen dari turbin yang penting dan berguna sebagai mengubah energi kinetik aliran fluida menjadi energi gerak putar atau aliran fluida masuk ke dalam turbin lalu menyentuh blade rotor turbin hasil dari adanya fluida kerja (air, angin, uap, dll). Dengan adanya fluida maka akan menghasilkan konversi energi yaitu potensial menjadi kinetik, mengubah kinetik menjadi mekanik. Perlu adanya komposisi dari blade turbin yang sesuai dengan fluida kerja yang menggerakkan sesuai 
variasi yang sesuai dengan kebutuhan untuk menggerakkan rotor turbin [6].

\section{Sudut Blade}

Sudut blade merupakan salah satu karakteristik yang dapat mempengaruhi kinerja turbin karena pada sudu turbin adalah tempat proses terjadinya energi kinetik air menjadi energi gerak pada rotor.

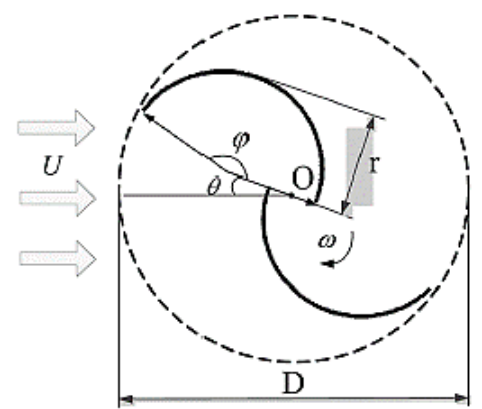

Gambar 4. Skematik dua dimensi pada turbin savonius

Gambar skematik dua dimensi dan parameter geometri pada turbin angin Savonius dua sudu bisa dilihat pada Gambar 4, di mana $U$ adalah kecepatan aliran, $\theta$ adalah sudut azimuth pada bagian sudu, $\varphi$ adalah sudut blade, $\omega$ adalah rotasi kecepatan pada turbin, $r$ adalah radius blade dan $D$ adalah diameter turbin [7].

\section{Computational Fluid Dynamics (CFD)}

Salah satu perangkat lunak yang dapat membuat prototipe virtual dari suatu sistem atau alat, dan menganalisis sistem dengan menggunakan CFD. Perangkat lunak CFD menyediakan gambar, hasil data atau grafik untuk memperlihatkan suatu nilai kinerja keahlian dalam program yang dirancang. Berbagai masalah pada dinamika fluida dapat memberikan suatu nilai kuantitatif dan kualitatif dengan hasil analisis CFD [8].

\section{E. Prinsip Bernoulli}

Dengan persamaan Bernoulli pada hubungan dalam aliran non viscous, terdapat keadaan antara tekanan dan kecepatan. Aliran tak termampatkan dapat diketahui pada segi rumus sebagai berikut.

$$
P+\frac{1}{2} \rho V^{2}=\text { konstan }
$$

Maka dengan tidak adanya gaya pada bodi pada aliran non viscous, persamaan tersebut menjadi :

$$
\rho \frac{D u}{D t}=-\frac{\partial p}{\partial x}
$$

atau

$$
\rho \frac{\partial u}{\partial t}+\rho \mathrm{u} \frac{\partial u}{\partial x}+\rho \mathrm{v} \frac{\partial u}{\partial y}+\rho \mathrm{w} \frac{\partial u}{\partial z}=-\frac{\partial p}{\partial x}
$$

$$
\mathrm{u}^{2}+\mathrm{v}^{2}+\mathrm{w}^{2}=V^{2}
$$

dan

$$
\begin{gathered}
\frac{\partial p}{\partial x} d x+\frac{\partial p}{\partial y} d y+\frac{\partial p}{\partial z} d z=d p \\
\frac{1}{2} d\left(\mathrm{u}^{2}+\mathrm{v}^{2}+\mathrm{w}^{2}\right)=-\frac{1}{\rho}\left(\frac{\partial p}{\partial x} d x+\frac{\partial p}{\partial y} d y+\frac{\partial p}{\partial z} d z\right)
\end{gathered}
$$

Dengan mensubstitusi persamaan (4) dan (5) ke persamaan (6), maka didapat :

$$
\frac{1}{2} d(V)^{2}=-\frac{d p}{\rho}
$$

atau

$$
d p=-\rho V d V
$$

Persamaan (8) merupakan persamaan Euler, yang berlaku untuk keadaan aliran tak kental, tidak ada gaya yang diterapkan pada benda dan relatif terhadap perubahan tekanan sepanjang garis arus $d p$ dan kecepatan $d V$ sepanjang garis arus yang sama. Persamaan (8) berpengaruh signifikan terhadap aliran tak termampatkan, dalam hal ini $\rho=$ konstan. Untuk aliran tak termampatkan maka persamaan (8) :

$$
\int_{p 1}^{p 2} d p=-\rho \int_{V !}^{V 2} V d V \quad \text { atau } \quad P_{2}-P_{1}=-\rho \frac{V_{2}^{2}}{2}-\frac{V_{1}^{2}}{2}
$$

lalu, menjadi

$$
P_{1}+\frac{1}{2} \rho V_{1}^{2}=P_{2}+\frac{1}{2} \rho V_{2}^{2}
$$

Dengan persamaan (10) ini merupakan persamaan Bernoulli, di mana $P_{1}$ relatif terhadap $V_{1}$ di titik 1 dan $P_{2}$ relatif terhadap $V_{2}$ di titik 2 yang mengalir sepanjang garis arus yang sama pada suatu aliran [9].

\section{F. Bilangan Reynolds}

Dengan bilangan Reynolds, jenis aliran dapat diketahui apakah aliran laminar atau turbulen. Aliran fluida yang melewati objek pada lapisan batas sangat bergantung pada bilangan Reynolds. Dapat diketahui bahwa gaya geser dan gaya inersia sangat penting dalam lapisan batas, dan bilangan Reynolds sendiri menggambarkan rasio gaya inersia terhadap gaya geser [10]. Berikut rumus aliran eksternal.

$$
R e=\frac{\text { Gaya inersia }}{\text { Gaya geser }}=\frac{p \times A}{\tau \times A}=\frac{\rho U_{\infty}^{2} L^{2}}{\left(\frac{\mu U_{\infty}}{L}\right) L^{2}}=\frac{\rho U_{\infty} L}{\mu}
$$

Sedangkan untuk aliran internal sebagai berikut.

$$
R e=\frac{\rho d v}{\mu}
$$

\section{METODE PENELITIAN/EKSPERIMEN}

Pada penelitian ini dilaksanakan dengan metode Computational Fluid Dynamics (CFD) melalui bantuan perangkat lunak Solidworks 2020 Flow Simulation. Turbin 
air Savonius ini memiliki diameter turbin sebesar $150 \mathrm{~mm}$, tinggi sudu turbin adalah $150 \mathrm{~mm}$ dan ketebalan turbin sebesar $1 \mathrm{~mm}$. Variasi jumlah sudu penelitian adalah 2, 3 dan 4 buah sudu. Lalu, variasi sudut blade yang digunakan adalah $90^{\circ}, 120^{\circ}$ dan $135^{\circ}$. Berikut diagram alir penelitian yang dilakukan pada Gambar 5.

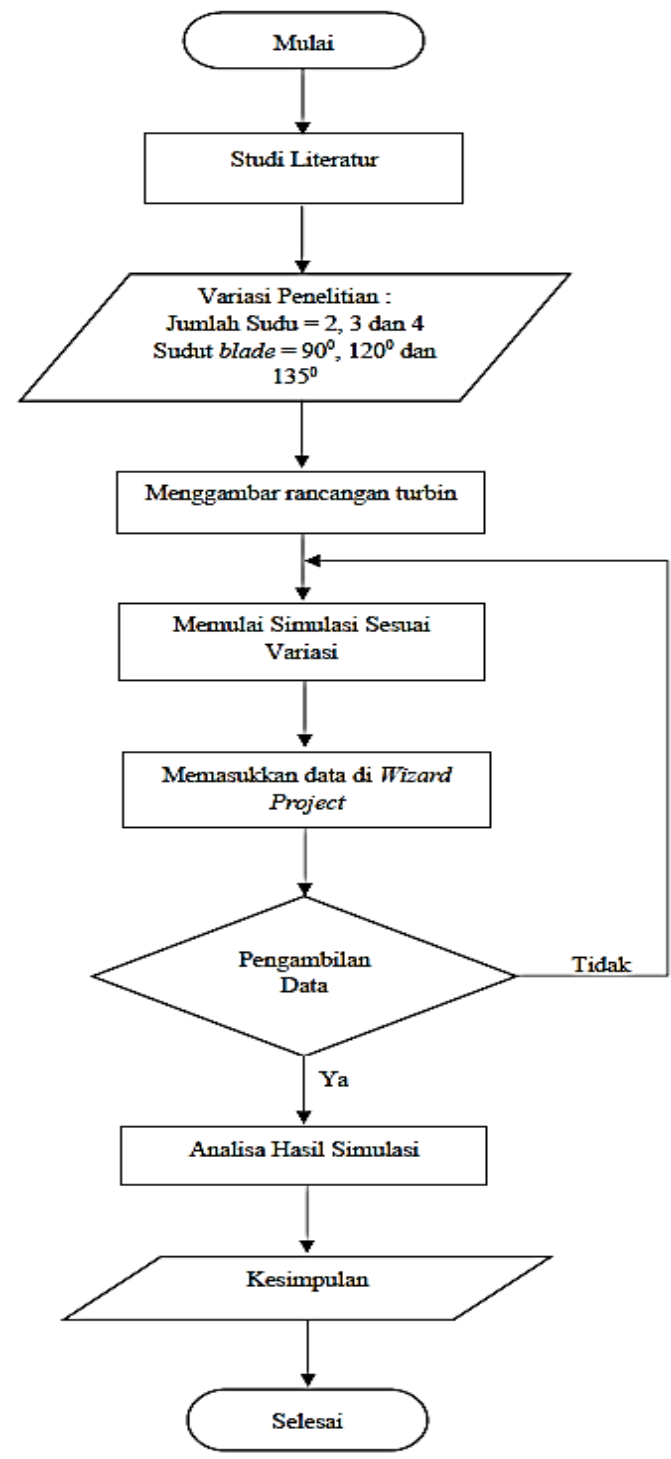

Gambar 5. Diagram alir penelitian

\section{HASIL DAN PEMBAHASAN}

\section{A. Hasil Data Distribusi Kecepatan}

Dari hasil simulasi didapat data dari masing-masing turbin. Berikut data distribusi kecepatan yang ditunjukkan pada Tabel 1 .

Tabel 1. Hasil data distribusi kecepatan

\begin{tabular}{|c|c|c|c|c|}
\hline \multirow[t]{2}{*}{ Turbin } & \multirow[t]{2}{*}{ Sudut } & \multicolumn{2}{|c|}{$\begin{array}{l}\text { Distribusi Kecepatan } \\
\qquad(\mathrm{m} / \mathrm{s})\end{array}$} & \multirow{2}{*}{$\begin{array}{c}\text { Rata-Rata } \\
\text { Distribusi } \\
\text { Kecepatan }(\mathrm{m} / \mathrm{s})\end{array}$} \\
\hline & & Maksimal & Minimal & \\
\hline \multirow{3}{*}{$2 \mathrm{Sudu}$} & $90^{\circ}$ & 1,768 & 0,048 & 1,430 \\
\hline & $120^{\circ}$ & 1,709 & 0,060 & 1,435 \\
\hline & $135^{\circ}$ & 1,663 & 0,069 & 1,437 \\
\hline 3 Sudu & $90^{\circ}$ & 1,618 & 0,049 & 1,425 \\
\hline
\end{tabular}

\begin{tabular}{lcccc}
\hline & $120^{\circ}$ & 1,620 & 0,070 & 1,431 \\
& $135^{\circ}$ & 1,639 & 0,100 & 1,435 \\
\hline \multirow{4}{*}{4 Sudu } & $90^{\circ}$ & 1,686 & 0,090 & 1,420 \\
& $120^{\circ}$ & 1,776 & 0,051 & 1,424 \\
& $135^{\circ}$ & 1,814 & 0,062 & 1,427 \\
\hline
\end{tabular}

Pada Tabel 1 terlihat bahwa distribusi kecepatan maksimal pada turbin 4 sudu dengan sudut blade $135^{\circ}$ pada simulasi ini yaitu sebesar $1,814 \mathrm{~m} / \mathrm{s}$ dan distribusi kecepatan minimal pada turbin 2 sudu dengan sudut blade $90^{\circ}$ sebesar $0,048 \mathrm{~m} / \mathrm{s}$. Rata-rata kecepatan tertinggi yang dihasilkan sebesar $1,437 \mathrm{~m} / \mathrm{s}$ pada turbin 2 sudu dengan sudut blade $135^{\circ}$ dan rata-rata kecepatan terendah pada turbin 4 sudu dengan sudut blade $90^{\circ}$ sebesar $1,420 \mathrm{~m} / \mathrm{s}$.

\section{B. Hasil Data Distribusi Tekanan}

Dari hasil simulasi didapat data dari masing-masing turbin. Berikut data distribusi tekanan yang ditunjukkan pada Tabel 2.

Tabel 2. Hasil data distribusi tekanan

\begin{tabular}{|c|c|c|c|c|}
\hline \multirow{2}{*}{ Turbin } & \multirow{2}{*}{ Sudut } & \multicolumn{2}{|c|}{ Distribusi Tekanan $(\mathrm{Pa})$} & \multirow{2}{*}{$\begin{array}{c}\text { Rata-Rata } \\
\text { Tekanan }(\mathrm{Pa})\end{array}$} \\
\hline & & Maksimal & Minimal & \\
\hline \multirow{3}{*}{$\begin{array}{c}2 \\
\text { Sudu }\end{array}$} & $90^{\circ}$ & $102.371,31$ & $100.577,71$ & $101.335,62$ \\
\hline & $120^{\circ}$ & $102.458,49$ & $100.705,75$ & $101.337,11$ \\
\hline & $135^{\circ}$ & $102.468,56$ & $100.786,08$ & $101.338,74$ \\
\hline \multirow{3}{*}{$\begin{array}{c}3 \\
\text { Sudu }\end{array}$} & $90^{\circ}$ & $102.402,02$ & $100.651,95$ & $101.333,97$ \\
\hline & $120^{\circ}$ & $102.425,03$ & $100.735,29$ & $101.333,41$ \\
\hline & $135^{\circ}$ & $102.436,97$ & $100.886,15$ & $101.333,71$ \\
\hline \multirow{3}{*}{$\begin{array}{c}4 \\
\text { Sudu }\end{array}$} & $90^{\circ}$ & $102.424,76$ & $100.780,03$ & $101.334,13$ \\
\hline & $120^{\circ}$ & $102.436,12$ & $100.060,72$ & $101.333,97$ \\
\hline & $135^{\circ}$ & $104.138,85$ & $99.656,88$ & 101.333 .21 \\
\hline
\end{tabular}

Pada Tabel 2 terlihat bahwa distribusi tekanan maksimal pada turbin 4 sudu dengan sudut blade $135^{\circ}$ pada simulasi ini yaitu sebesar $104.138,85 \mathrm{~Pa}$ dan distribusi tekanan minimal pada turbin 4 sudu dengan sudut blade $135^{\circ}$ sebesar 99.656,88 Pa. Rata-rata tekanan tertinggi yang dihasilkan sebesar $101.338,74 \mathrm{~Pa}$ pada turbin 2 sudu dengan sudut blade $135^{\circ}$ dan rata-rata tekanan terendah pada turbin 4 sudu dengan sudut blade $135^{\circ}$ sebesar 101.333,21 Pa.

\section{Turbin 2 Sudu}

Hasil dari simulasi yang dilakukan pada turbin 2 sudu dalam bentuk distribusi kecepatan dan tekanan disajikan pada Gambar 6 dan 7 sebagai berikut. 


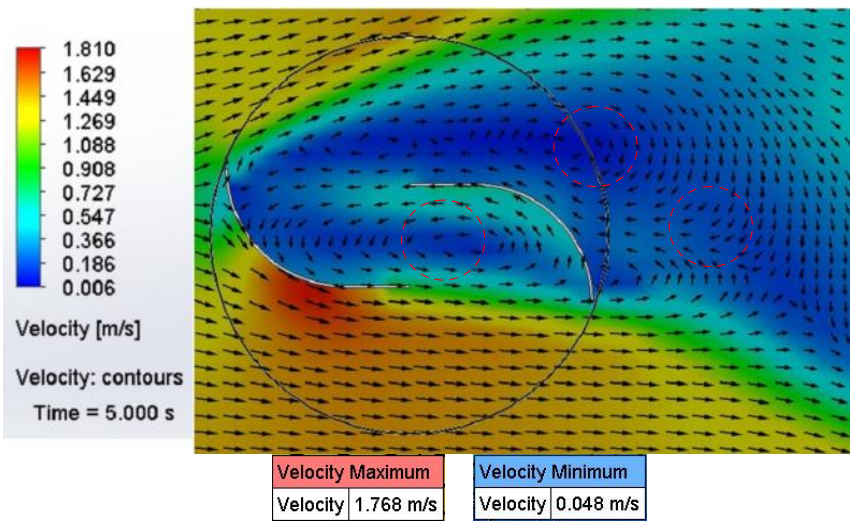

(a)

(a)

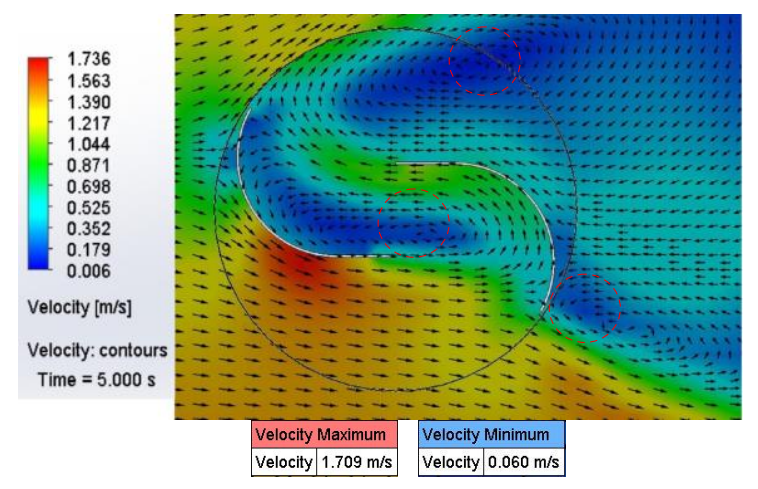

(b)

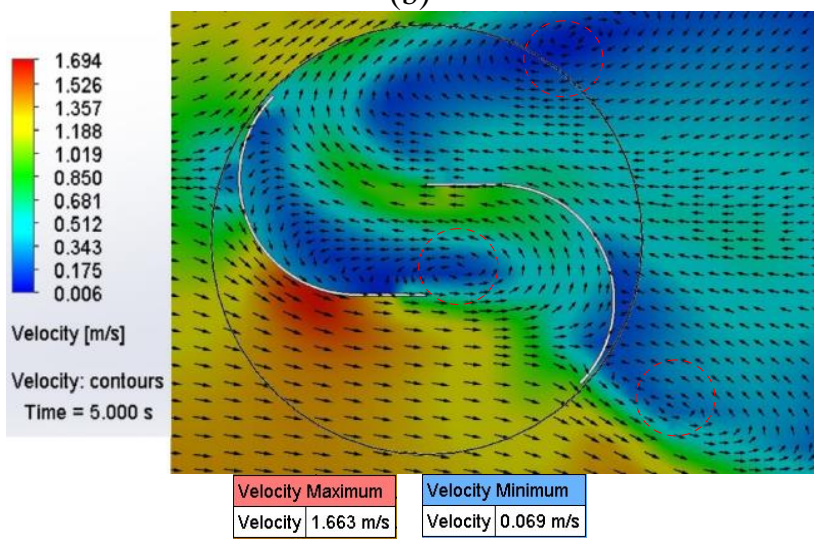

(c)

Keterangan :

(1) = Terjadinya pusaran (vortex)

Gambar 6. Distribusi kecepatan pada turbin 2 sudu (a) $90^{\circ}$, (b) $120^{\circ}$ dan (c) $135^{\circ}$

Pada Gambar 6 merupakan cut plot velocity dari turbin 2 sudu dengan sudut blade $90^{\circ}, 120^{\circ}$ dan $135^{\circ}$. Pada Gambar 6 (a), diawali dengan aliran masuk, aliran tersebut menabrak sudu sehingga aliran berlawanan arah dan hal tersebut dapat berpengaruh pada kecepatan serta tekanannya. Bisa dilihat pada sisi bagian bawah sudu, kontur warna yang terjadi disini terdapat warna merah yang terfokus di satu sisi, sedikit warna hijau dan biru muda serta didominasi warna jingga maka dapat dikatakan kecepatannya cukup tinggi. Sedangkan pada sisi atas sudu didominasi dengan warna biru tua dan dengan gradasi warna yang cukup bisa dikatakan bahwa di atas sisi sudu kecepatannya cukup rendah sehingga distribusi kecepatannya hanya terfokus di salah satu sisi sudu saja. Terlihat ada beberapa pusaran air pada turbin yang berpengaruh pada kecepatannya.

Pada Gambar 6 (b), diawali aliran masuk dengan menabrak dinding sudu dan kontur mulai menunjukkan warna biru tua yang artinya kecepatan semakin rendah, hal ini menunjukkan bahwa seiring bertambahnya sudut, aliran yang masuk ke dalam rotor semakin sulit. Dapat dilihat pada sisi bagian bawah dan atas sudu, kontur warna yang sebelumnya terjadi pada sudut $90^{\circ}$ mengalami penyebaran. Pada sisi bagian bawah sudu, didominasi oleh warna kuning-jingga dan warna merah yang terfokus di satu sisi serta sedikit warna hijau dan biru muda maka dapat dikatakan bahwa kecepatan cukup tinggi. Lalu pada sisi atas sudu, aliran mulai menyebar dengan didominasi oleh warna biru muda-biru tua dengan sedikit warna hijau. Terlihat ada beberapa pusaran air pada turbin yang berpengaruh pada kecepatannya.

Pada Gambar 6 (c), diawali dengan aliran masuk, aliran tersebut menabrak dinding sudu dan kontur yang sebelumya terjadi pada sudut $120^{\circ}$ semakin meningkat. Hal ini memperkuat adanya pernyataan bahwa seiring sudut bertambah maka aliran yang masuk akan semakin sulit sehingga kecepatan yang diterima rendah pada awal masuk rotor, akan tetapi aliran menjadi menyebar dan menyebabkan distribusi kecepatannya meningkat. Pada sisi bagian bawah sudu, didominasi oleh warna kuningjingga dan warna merah yang terfokus di satu sisi serta sedikit warna hijau dan biru muda maka dapat dikatakan bahwa kecepatan cukup tinggi. Lalu pada sisi atas sudu, aliran mulai menyebar dengan didominasi oleh warna biru muda-biru tua dengan sedikit warna hijau dibagian atas. Disebelah kanan sudu terlihat kontur berwarna biru tua yang semakin pekat itu artinya kecepatan semakin rendah dan tekanan semakin tinggi. Terlihat ada beberapa pusaran air pada turbin yang berpengaruh pada kecepatannya.

Terlihat pada tanda di masing-masing sudu terlihat semacam pusaran dan kemudian arus berbelok, hal ini juga berpengaruh pada distribusi kecepatan. Dengan adanya boundary layer yang terpisah dari dinding juga mempengaruhi sehingga mengakibatkan terjadinya pusaran air, adanya pusaran air ini akan mengganggu pola aliran laminer sehingga akan muncul aliran turbulensi [11].

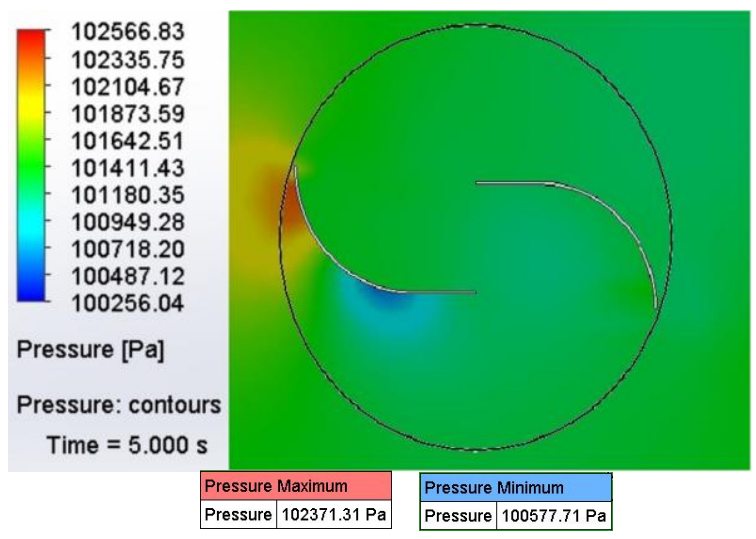

(a) 


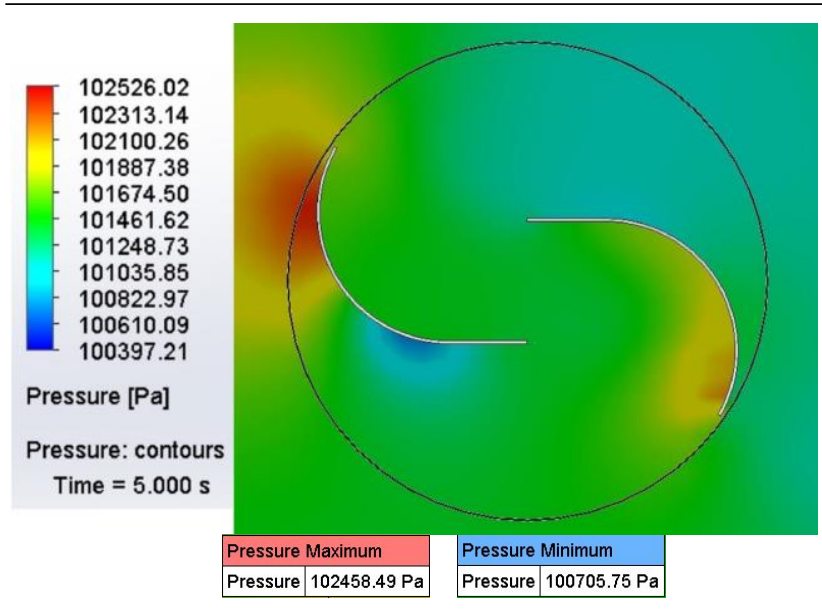

(b)

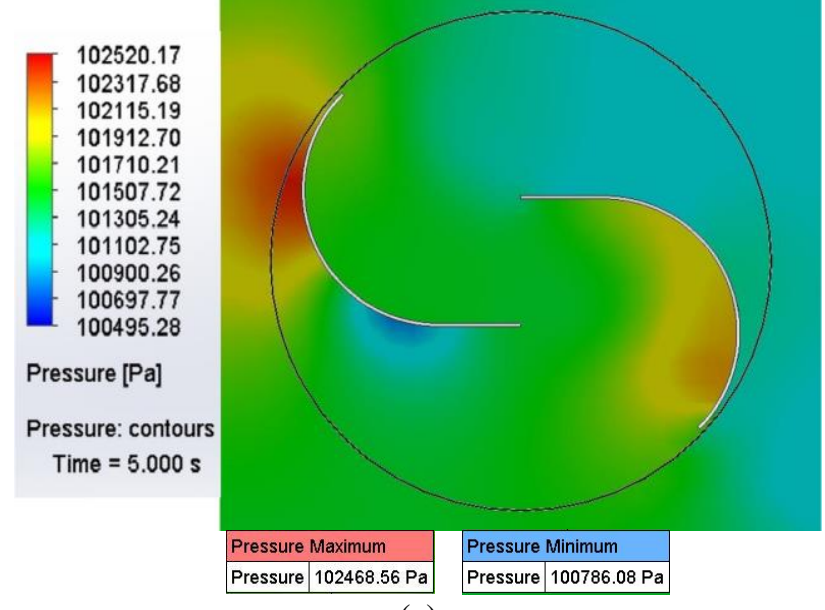

(c)

Gambar 7. Distribusi tekanan pada turbin 2 sudu (a) $90^{\circ}$, (b) $120^{\circ}$ dan (c) $135^{\circ}$

Pada Gambar 7 merupakan cut plot pressure dari turbin 2 sudu dengan sudut blade $90^{\circ}, 120^{\circ}$ dan $135^{\circ}$. Pada Gambar 7 (a), diawali dengan aliran masuk di sisi sebelah kiri sudu, kontur berwarna jingga kekuningan dan diikuti dengan warna hijau kemudian warna biru ke biru muda pada bagian bawah sudu serta pada sudut ini kontur didominasi gradasi warna hijau-biru muda yang artinya tekanan yang dihasilkan cukup.

Pada Gambar 7 (b), diawali dengan aliran masuk di sisi sebelah kiri sudu, mengalami gradasi warna yang ekstrem dan diikuti dengan warna kuning, hijau kemudian warna biru ke biru muda pada bagian bawah sudu serta pada sudut ini kontur didominasi gradasi warna hijau-biru muda yang artinya tekanan yang dihasilkan cukup tinggi. Di bagian kanan sudu, mulai terlihat adanya tekanan yang cukup tinggi dengan kontur warna kuning-jingga diikuti dengan warna hijau dan di sisi bagian atas tekanan terlihat cukup rendah.

Pada Gambar 7 (c), diawali dengan aliran masuk di sisi sebelah kiri sudu, mengalami gradasi warna yang ekstrem dan diikuti dengan warna kuning, hijau kemudian warna biru ke biru muda pada bagian bawah sudu serta pada sudut ini kontur didominasi gradasi warna hijau-biru muda yang artinya tekanan yang dihasilkan cukup tinggi. Di bagian kanan sudu, tekanan mulai terlihat menyebar cukup tinggi dengan kontur warna kuning-jingga diikuti dengan warna hijau dan di sisi bagian atas tekanan terlihat cukup rendah.

Hasil dari ketiga sudu ini tidak merata secara luas, ketiga sudu ini terlihat tekanan akibat kecepatan air tidak merata secara luas sehingga dengan adanya peningkatan sudut blade tidak berpengaruh dan tekanan terus meningkat di setiap sudutnya. Terlihat bahwa ketiga turbin tersebut mendapat tekanan yang cukup lumayan tinggi di setiap sisinya. Tekanan yang tinggi akan meningkatkan kecepatan dorongan air yang keluar untuk mendorong rotor turbin agar berputar, sehingga dapat dikatakan bahwa semakin meningkatnya tekanan maka akan menyebabkan putaran turbin semakin cepat [12]. Pada gambar di atas terlihat ada beberapa perbedaan, ketika kecepatan meningkat tekanan justru menurun dan sebaliknya. Hal ini dapat dikatakan bahwa turbin tersebut terdapat hukum Bernoulli seperti yang dirumuskan pada persamaan (10).

\section{Turbin 3 Sudu}

Hasil dari simulasi yang dilakukan pada turbin 3 sudu dalam bentuk distribusi kecepatan dan tekanan disajikan pada Gambar 8 dan 9 sebagai berikut.

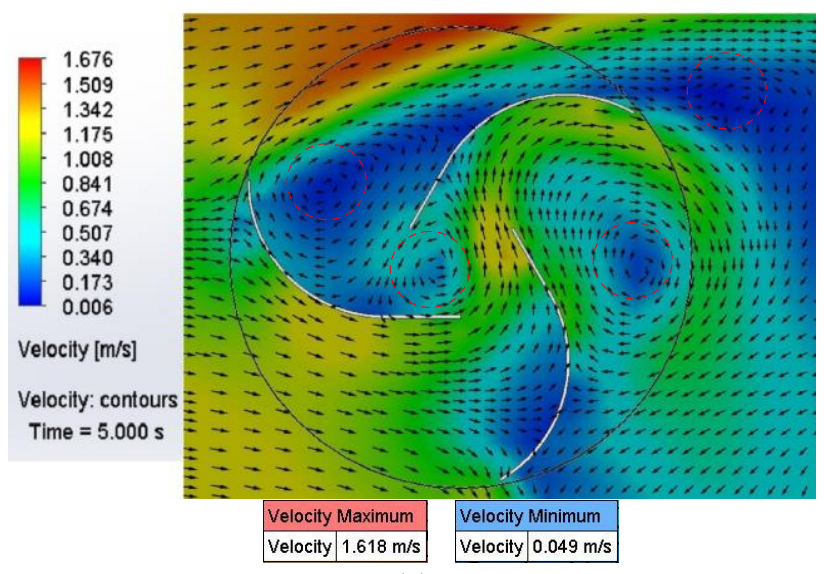

(a)

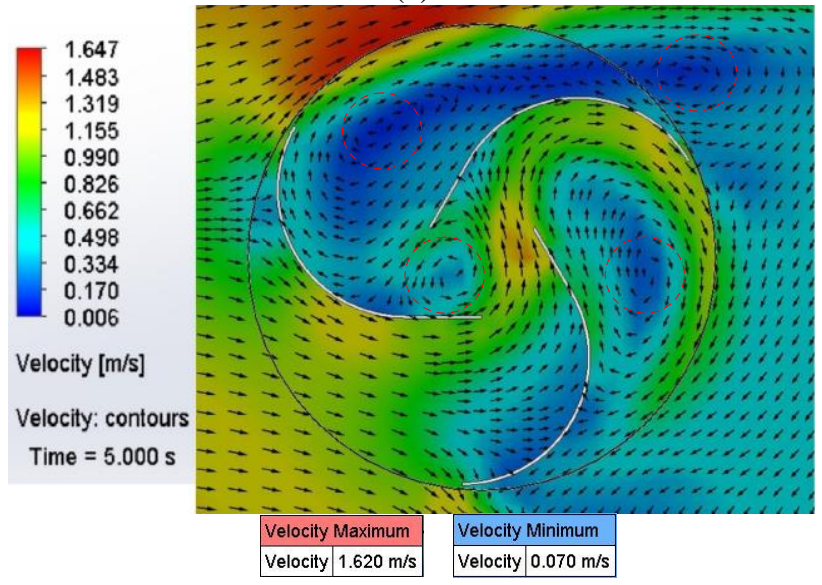

(b) 


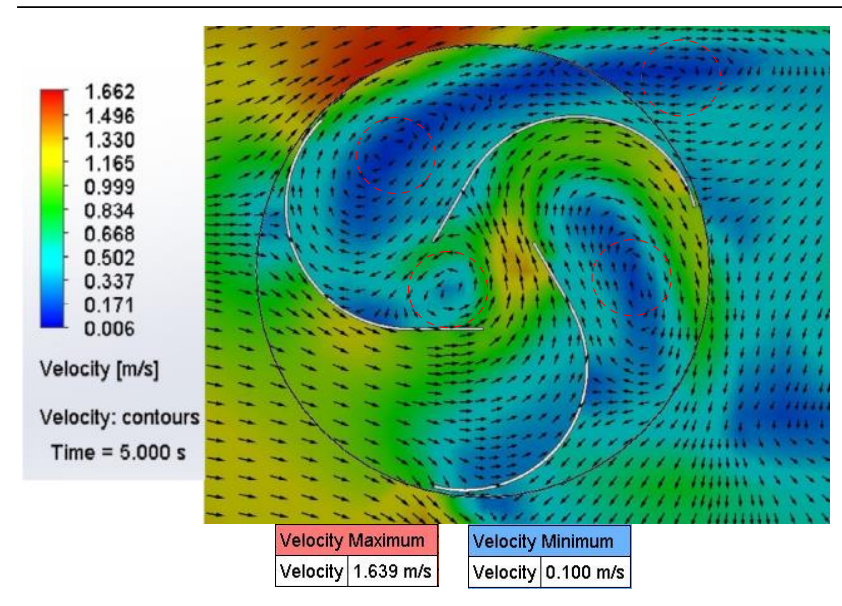

(c)

Keterangan :

$$
\text { , = Terjadinya pusaran (vortex) }
$$

Gambar 8. Distribusi kecepatan pada turbin 3 sudu (a) $90^{\circ}$, (b) $120^{\circ}$ dan (c) $135^{\circ}$

Pada Gambar 8 merupakan cut plot velocity dari turbin 3 sudu dengan sudut blade $90^{\circ}, 120^{\circ}$ dan $135^{\circ}$. Pada Gambar 8 (a), diawali dengan aliran masuk, aliran tersebut menabrak sudu sehingga aliran berlawanan arah dan terlihat kecepatan arah aliran di sisi bagian atas tersebut tinggi, akan tetapi kecepatan tersebut tidak berada di pada sudu turbin jadi hal tersebut tidak menimbulkan tekanan pada sudu turbin. Di bagian bawah didominasi oleh gradasi kuning-hijau dan di bagian bawah sudu kecepatan mulai rendah dan tidak ada terjadinya pusaran, jadi pada bagian tersebut terdapat tekanan yang cukup tinggi. Terlihat ada peningkatan pusaran pada turbin 3 sudu ini, menyebabkan kecepatan akan semakin rendah.

Pada Gambar 8 (b), diawali dengan aliran masuk, aliran tersebut menabrak sudu sehingga aliran berlawanan arah dan terlihat lebih menyebar karena akibat penambahan sudut dari sebelumnya lalu kecepatannya pada arah aliran di sisi bagian atas tersebut lebih tinggi dari sudut sebelumnya, akan tetapi kecepatan tersebut tidak berada di pada sudu turbin jadi hal tersebut tidak menimbulkan tekanan pada sudu turbin. Di bagian bawah didominasi oleh gradasi kuning-hijau dan di bagian bawah sudu kecepatan mulai menyebar dan gradasi warnanya mulai berubah dari sebelumnya dan disitu tidak ada terjadinya pusaran, jadi pada bagian tersebut terdapat tekanan yang cukup tinggi. Terlihat ada peningkatan pusaran pada turbin 3 sudu ini, menyebabkan kecepatan akan semakin rendah.

Pada Gambar 8 (c), diawali dengan aliran masuk, aliran tersebut menabrak sudu sehingga aliran berlawanan arah dan terlihat lebih menyebar karena akibat penambahan sudut dari sebelumnya lalu kecepatannya pada arah aliran di sisi bagian atas tersebut lebih tinggi dari sudut sebelumnya, akan tetapi kecepatan tersebut tidak berada di pada sudu turbin jadi hal tersebut tidak berpengaruh pada turbin. Di bagian bawah didominasi oleh gradasi kuninghijau dan di bagian bawah sudu kecepatan mulai menyebar dan gradasi warnanya mulai berubah dari sebelumnya dan disitu tidak ada terjadinya pusaran, jadi pada bagian tersebut terdapat tekanan yang cukup tinggi. Terlihat ada peningkatan pusaran pada turbin 3 sudu ini, menyebabkan kecepatan akan semakin rendah.

Di beberapa bagian dan belakang sudu, terjadi semacam pusaran yang mengakibatkan distribusi kecepatan semakin menurun. Oleh karena itu, pusaran air (vortex) sangat berpengaruh pada distribusi kecepatan, terlihat juga bahwa pusaran air bertambah seiring bertambahnya sudu. Distribusi kecepatan di setiap sudunya terlihat merata, hal ini sangat berpotensi untuk memberikan dorongan pada sudu yang pada akhirnya akan memberikan kecepatan putar yang lebih tinggi pada rotor turbin [13].

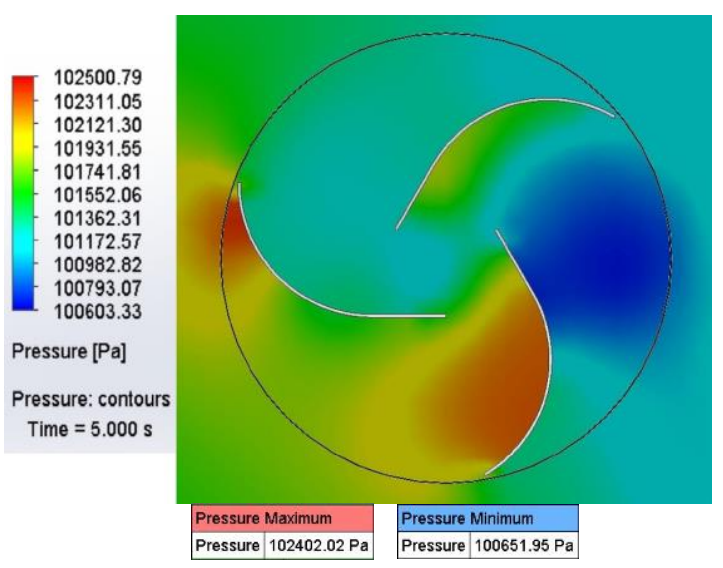

(a)

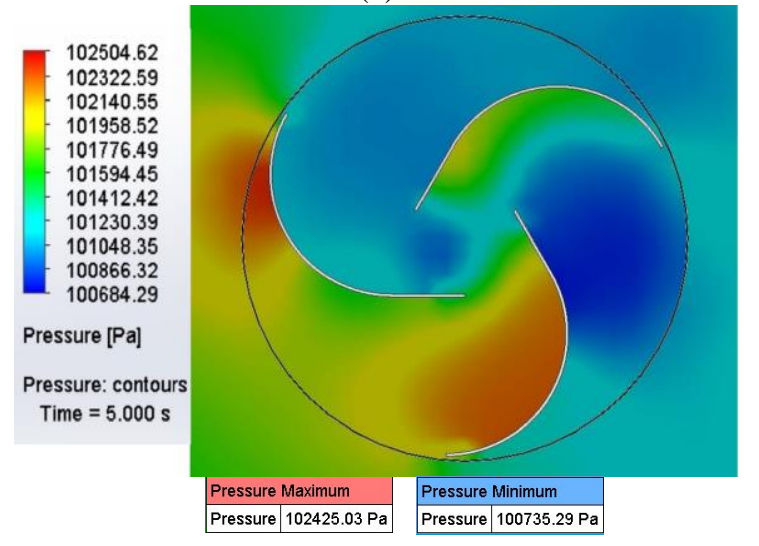

(b)

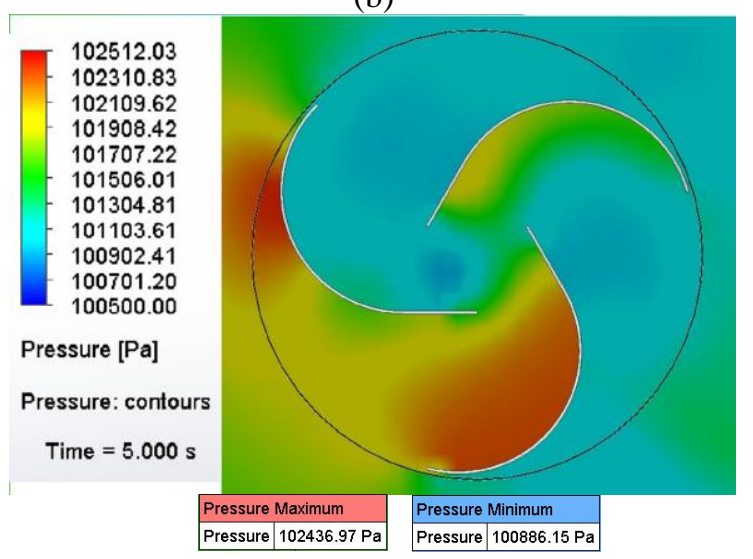

(c)

Gambar 9. Distribusi tekanan pada turbin $3 \mathrm{Sudu}$ (a) $90^{\circ}$, (b) $120^{\circ}$ dan (c) $135^{\circ}$ 
Pada Gambar 9 merupakan cut plot pressure dari turbin 3 sudu dengan sudut blade $90^{\circ}, 120^{\circ}$ dan $135^{\circ}$. Pada Gambar 9 (a), diawali dengan aliran masuk di sisi sebelah kiri sudu, kontur berwarna merah dan diikuti dengan warna jingga-kuning, kemudian hijau. Pada bagian bawah sudu terdapat kontur jingga tekanan berfokus di bagian bawah sehingga dibagian bawah sudu tekanan cukup tinggi. Lalu pada bagian atas sudu kontur didominasi gradasi warna biru muda dengan sedikit hijau yang artinya tekanan yang dihasilkan cukup rendah. Terlihat bahwa tekanan akibat kecepatan pada sudut ini sedikit kurang terdistribusi secara merata dibandingkan sudut $120^{\circ}$ dan sudut $135^{\circ}$

Pada Gambar 9 (b), diawali dengan aliran masuk di sisi sebelah kiri sudu, kontur berwarna merah dan diikuti dengan warna jingga-kuning, kemudian sedikit hijau. Pada bagian bawah sudu terdapat kontur jingga tekanan berfokus di bagian bawah sehingga dibagian bawah sudu tekanan cukup tinggi. Lalu pada bagian atas sudu kontur didominasi gradasi warna biru muda yang artinya tekanan yang dihasilkan rendah. Hasil simulasi terlihat bahwa tekanan akibat kecepatan terdistribusi secara merata. Sehingga lebih optimal dalam memberikan torsi pada sudu.

Pada Gambar 9 (c), diawali dengan aliran masuk di sisi sebelah kiri sudu, kontur berwarna merah dan diikuti dengan warna jingga-kuning, kemudian sedikit hijau. Pada bagian bawah sudu terdapat kontur jingga tekanan berfokus di bagian bawah sehingga dibagian bawah sudu tekanan cukup tinggi. Lalu pada bagian atas sudu kontur didominasi gradasi warna biru muda yang artinya tekanan yang dihasilkan rendah dan pada bagian kanan sudu terlihat perbedaan antara sudut sebelumnya kontur sebelumnya berwarna biru tua, ketika pada sudut 135 sisi bagian kanan kontur berwarna biru muda sehingga tekanan di sudut ini naik.

Hasil simulasi pada Gambar 4 (b) dan (c) terlihat bahwa tekanan akibat kecepatan terdistribusi secara merata, sehingga lebih optimal dalam memberikan torsi pada sudu. Jika aliran lebih terkonsentrasi dan merata maka kemampuan rotor blade lebih optimal melakukan putaran poros turbin [14]

\section{E. Turbin 4 Sudu}

Hasil dari simulasi yang dilakukan pada turbin 4 sudu dalam bentuk distribusi kecepatan dan tekanan disajikan pada Gambar 10 dan 11 sebagai berikut.

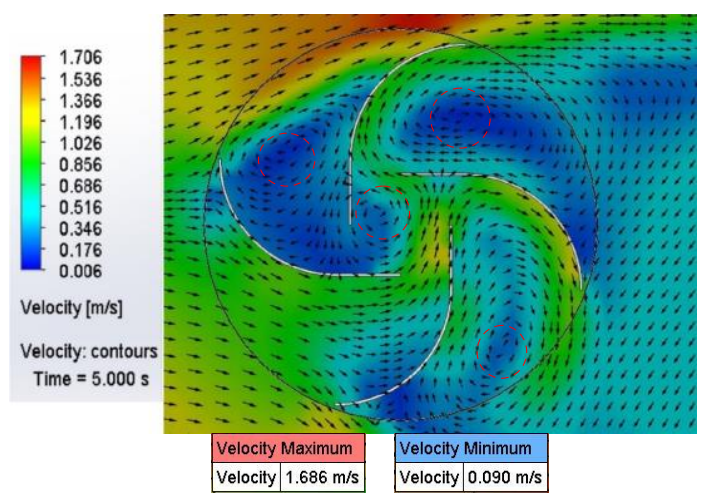

(a)

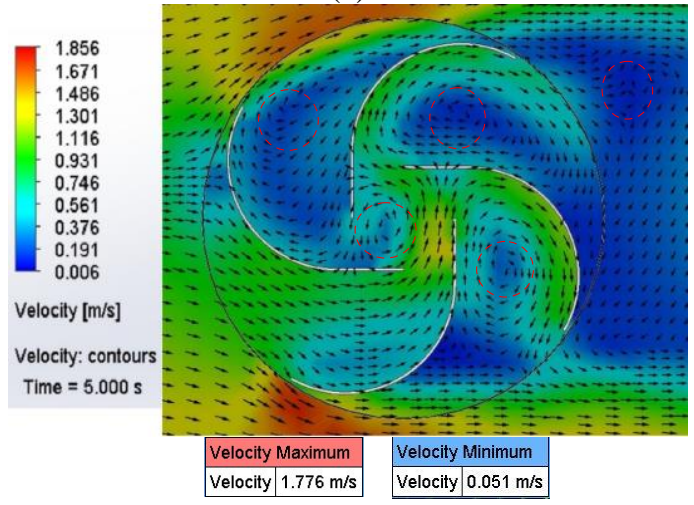

(b)

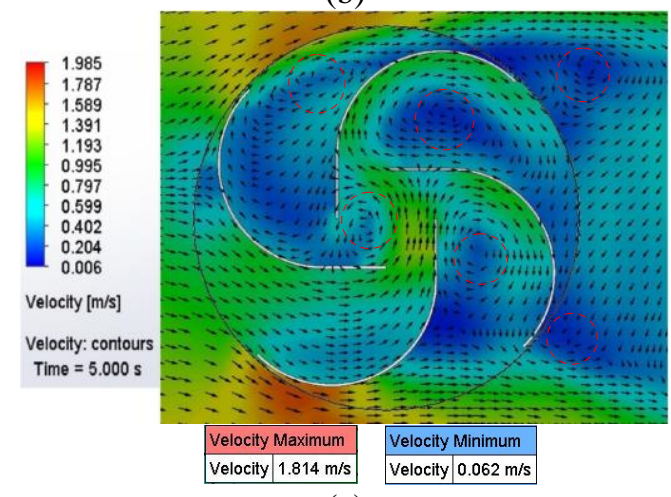

(c)

Keterangan :

$$
i_{1},=\text { Terjadinya pusaran (vortex) }
$$

Gambar 10. Distribusi kecepatan pada turbin 4 sudu (a) $90^{\circ}$, (b) $120^{\circ}$ dan (c) $135^{\circ}$

Pada Gambar 10 merupakan cut plot velocity dari turbin 4 sudu dengan sudut blade $90^{\circ}, 120^{\circ}$ dan $135^{\circ}$. Pada Gambar 10 (a), diawali dengan aliran masuk, aliran tersebut menabrak sudu sehingga aliran berlawanan arah dan terlihat kecepatan arah aliran di sisi bagian atas tersebut tinggi hampir sama dengan turbin 3 sudu dengan sudut $90^{\circ}$, akan tetapi kecepatan tersebut tidak berada di pada sudu turbin jadi hal tersebut tidak menimbulkan tekanan pada sudu turbin. Di bagian bawah didominasi oleh gradasi hijau-biru dan di bagian bawah sudu kecepatan mulai rendah dan tidak ada terjadinya pusaran, jadi pada bagian tersebut terdapat tekanan yang cukup tinggi. Di ketiga ruang sudunya terlihat kontur didominasi oleh gradasi biru. Terlihat ada beberapa dan peningkatan pusaran pada turbin 4 sudu ini, menyebabkan kecepatan akan semakin rendah.

Pada Gambar 10 (b), diawali dengan aliran masuk, aliran tersebut menabrak sudu sehingga aliran berlawanan arah dan terlihat lebih menyebar karena akibat penambahan sudut dari sebelumnya lalu kecepatannya pada arah aliran dari sudut sebelumnya di sisi bagian atas tersebut tinggi lalu titik tertinggi kecepatan berpindah pada sisi bagian bawah, akan tetapi kecepatan tersebut tidak berada di pada sudu turbin jadi hal tersebut tidak menimbulkan tekanan pada sudu turbin. Di bagian bawah didominasi oleh gradasi hijau-biru muda dan di bagian bawah sudu kecepatan mulai menyebar dan gradasi warnanya mulai 
berubah dari sebelumnya dan aliran terlihat mulai memasuki bagian bawah sudu serta disitu tidak ada terjadinya pusaran, jadi pada bagian tersebut terdapat tekanan yang cukup tinggi. Di ketiga ruang sudunya terlihat kontur didominasi oleh gradasi biru dan terlihat menyebar daripada sudut sebelumnya, di kanan bagian bawah kontur biru tua mulai terlihat. Terlihat ada peningkatan pusaran pada turbin 4 sudu ini, menyebabkan kecepatan akan semakin rendah.

Pada Gambar 10 (c), diawali dengan aliran masuk, aliran tersebut menabrak sudu sehingga aliran berlawanan arah dan terlihat lebih menyebar karena akibat penambahan sudut lalu kecepatannya pada arah aliran dari sisi bagian atas dan sisi bagian bawah tidak ada gradasi warna yang ekstrem, akan tetapi kecepatan tersebut tidak berada di pada sudu turbin jadi hal tersebut tidak menimbulkan tekanan pada sudu turbin. Di bagian bawah didominasi oleh gradasi biru muda-hijau dan di bagian bawah sudu kecepatan mulai menyebar dan gradasi warnanya mulai berubah dari sebelumnya dan aliran terlihat menyebar dengan memasuki bagian bawah sudu serta disitu tidak ada terjadinya pusaran, jadi pada bagian tersebut terdapat tekanan yang cukup tinggi. Di ketiga ruang sudunya terlihat kontur didominasi oleh gradasi biru dan terlihat menyebar daripada sudut sebelumnya, di kanan bagian bawah kontur biru tua terlihat menyebar. Terlihat ada peningkatan pusaran pada turbin 4 sudu ini, menyebabkan kecepatan akan semakin rendah.

Pada turbin 4 sudu ini, pusaran semakin bertambah yang menyebabkan kecepatan semakin rendah. Pusaran air yang tinggi kurang baik untuk putaran rotor yang dapat mengakibatkan hambatan pada sudu sehingga gaya dorong dari aliran air tidak mendorong sudu tersebut dan putaran ke rotor menjadi tidak maksimal [14].

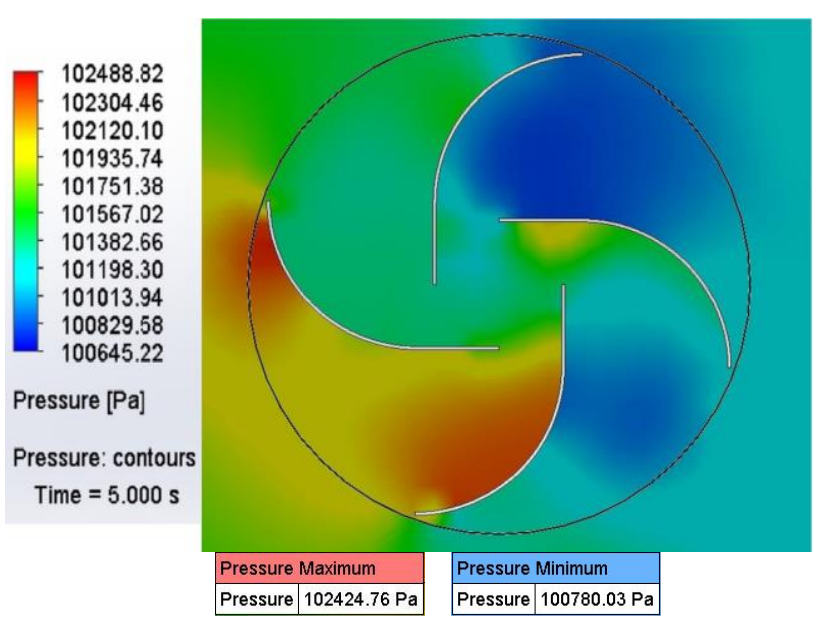

(a)

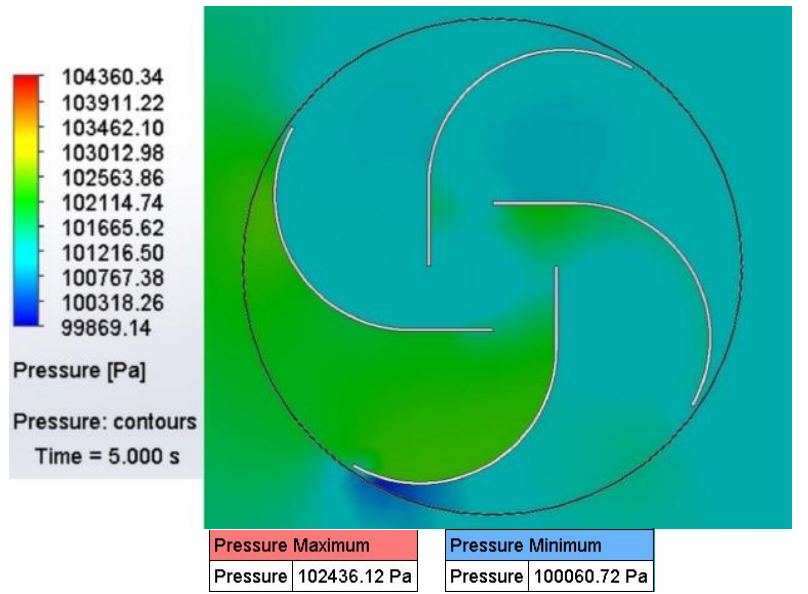

(b)

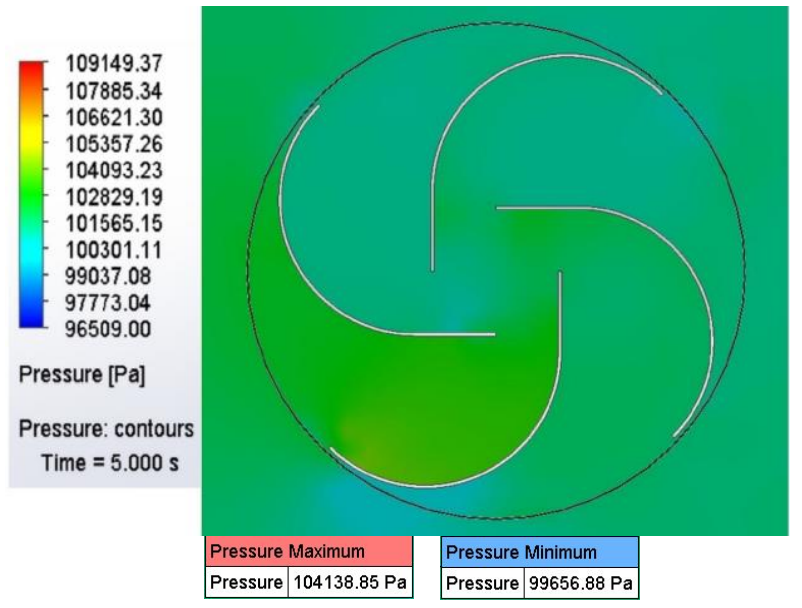

(c)

Gambar 11. Distribusi tekanan pada turbin 4 sudu (a) $90^{\circ}$, (b) $120^{\circ}$ dan (c) $135^{\circ}$

Pada Gambar 11 merupakan cut plot pressure dari turbin 4 sudu dengan sudut blade $90^{\circ}, 120^{\circ}$ dan $135^{\circ}$. Pada Gambar 11 (a) diawali dengan aliran masuk di sisi sebelah kiri sudu, kontur berwarna merah dan diikuti dengan warna jingga-kuning. Pada bagian bawah sudu terdapat kontur jingga sehingga tekanan yang dihasilkan di bagian bawah sudu mendapat tekanan yang cukup tinggi. Lalu pada bagian atas kiri kontur didominasi gradasi warna biru muda-hijau yang artinya tekanan yang dihasilkan cukup. Selanjutnya, pada bagian atas kanan terlihat gradasi warna sangat rendah dibandingkan dengan sisi kanan bagian bawah. Terlihat bahwa tekanan akibat kecepatan pada sudut ini sedikit kurang terdistribusi secara merata dibandingkan sudut $120^{\circ}$ dan sudut $135^{\circ}$.

Pada Gambar 11 (b), diawali dengan aliran masuk di sisi sebelah kiri sudu, kontur berwarna hijau dengan sedikit kuning. Pada bagian bawah sudu hanya terdapat gradasi hijau dan tidak ada gradasi warna yang ekstrem. Lalu pada di ketiga ruang sudu kontur didominasi gradasi warna biru muda yang artinya tekanan yang dihasilkan rendah. Hasil simulasi terlihat bahwa tekanan akibat kecepatan terdistribusi secara merata. Sehingga lebih optimal dalam memberikan torsi pada sudu.

Pada Gambar 11 (c), diawali dengan aliran masuk di sisi sebelah kiri sudu, kontur berwarna hijau dengan sedikit kuning. Pada bagian bawah sudu hanya terdapat gradasi 
hijau dan tidak ada gradasi warna yang ekstrem. Lalu pada di ketiga ruang sudu kontur didominasi gradasi warna biru muda yang artinya tekanan yang dihasilkan rendah. Hasil simulasi terlihat bahwa tekanan akibat kecepatan terdistribusi secara merata. Sehingga lebih optimal dalam memberikan torsi pada sudu, semakin kecil perbedaan rata-rata distribusi tekanan maka akan semakin baik [14]. Hal tersebut berbanding lurus dengan unjuk kerja rotor, karena berbanding lurus dengan energi putaran, torsi dan daya yang dapat dihasilkan oleh putaran poros pada rotor turbin.

\section{F. Hubungan Variasi Sudut Terhadap Kecepatan}

Dari hasil data yang sudah didapat kemudian di rangkai menjadi sebuah grafik. Berikut grafik kecepatan yang ditunjukkan pada Gambar 12.

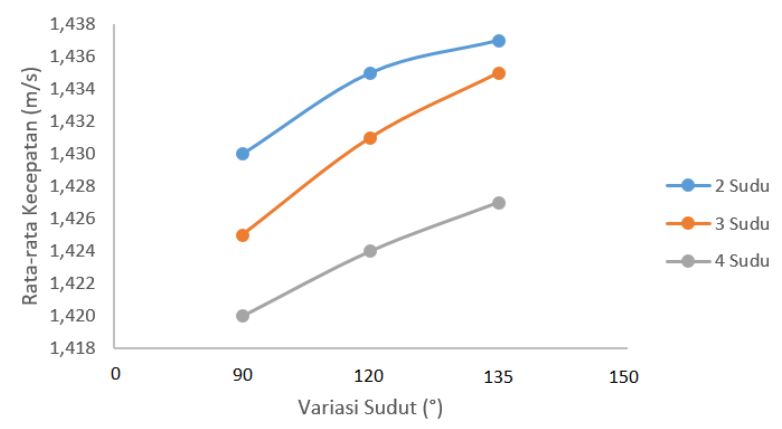

Gambar 12. Grafik hubungan variasi sudut dengan kecepatan

Dilihat pada Gambar 12 bahwa variasi sudut berbanding lurus dengan kecepatan yang dihasilkan hal ini dapat dibuktikan dengan kecepatan pada masing-masing sudu di setiap variasi sudut semuanya naik, artinya semakin besar variasi sudut yang diberikan, maka semakin besar energi yang diberikan oleh air terhadap turbin maka energi yang dapat dikonversikan turbin menjadi semakin meningkat. Dari grafik di atas dapat dilihat bahwa kecepatan maksimal yang dihasilkan turbin terjadi pada turbin 2 sudu dengan kecepatan $1,437 \mathrm{~m} / \mathrm{s}$ pada variasi sudut $135^{\circ}$. Sedangkan untuk kecepatan minimal yang dihasilkan turbin terjadi pada turbin 4 sudu dengan kecepatan $1,420 \mathrm{~m} / \mathrm{s}$ pada variasi sudut $90^{\circ}$.

\section{G. Hubungan Variasi Sudut Terhadap Tekanan}

Dari hasil data yang sudah didapat kemudian di rangkai menjadi sebuah grafik. Berikut grafik tekanan yang ditunjukkan pada Gambar 13.

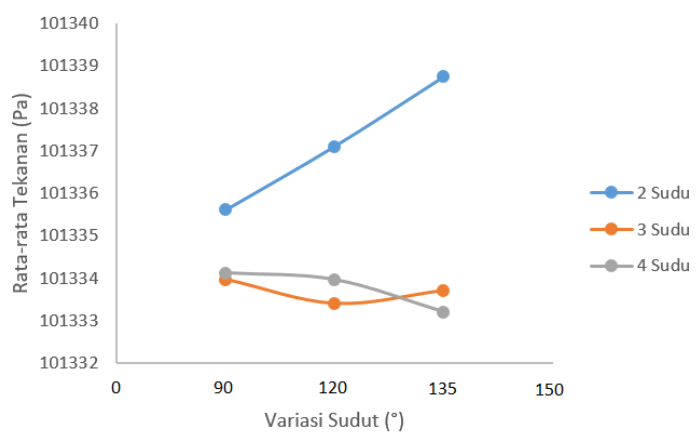

Gambar 13. Grafik hubungan variasi sudut dengan tekanan
Dilihat pada Gambar 13 bahwa variasi sudut tidak berbanding lurus dengan tekanan yang dihasilkan, hal ini dapat dibuktikan dengan hasil tekanan dari variasi sudut yang berbeda-beda yaitu turbin 2 sudu yang tekanannya naik di setiap variasi sudutnya. Lalu turbin 4 sudu yang tekanannya turun di setiap variasi sudutnya, sedangkan pada turbin 3 sudu tekanannya mengalami fluktuasi di setiap variasi sudutnya. Dari grafik di atas dapat dilihat bahwa tekanan maksimal yang dihasilkan turbin terjadi pada turbin 2 sudu sebesar 101.338,74 Pa pada variasi sudut $135^{\circ}$. Sedangkan untuk tekanan minimal yang dihasilkan turbin terjadi pada turbin 4 sudu sebesar $101.333,21$ Pa pada variasi sudut $135^{\circ}$.

\section{KESIMPULAN}

Distribusi kecepatan rata-rata paling tinggi terjadi pada turbin 2 sudu dengan sudut blade $135^{\circ}$ yaitu $1,437 \mathrm{~m} / \mathrm{s}$ dengan titik maksimal sebesar $1,663 \mathrm{~m} / \mathrm{s}$ dan titik minimal sebesar $0,069 \mathrm{~m} / \mathrm{s}$. Sedangkan yang paling rendah terjadi pada turbin 4 sudu dengan sudut blade $90^{\circ}$ yaitu $1,420 \mathrm{~m} / \mathrm{s}$ dengan titik maksimal yang didapatkan sebesar 1,686 m/s dan titik minimal sebesar $0,090 \mathrm{~m} / \mathrm{s}$. Jumlah sudu dan sudut blade berpengaruh pada kecepatan yang dihasilkan, yang di mana semakin bertambahnya jumlah sudu maka nilai kecepatan semakin kecil. Lalu, jika sudut blade semakin meningkat maka nilai kecepatan yang dihasilkan semakin besar.

Turbin dengan jumlah 2 sudu dengan sudut blade $135^{\circ}$ dengan titik maksimal sebesar 102.468,56 Pa dan titik minimal sebesar 100.786,08 Pa memberikan perbedaan distribusi rata-rata tekanan paling tinggi yaitu 101.338,74 $\mathrm{Pa}$. Sedangkan turbin dengan jumlah 4 sudu dengan sudut blade $135^{\circ}$ dengan titik maksimal sebesar 104.138,85 Pa dan titik minimal sebesar 99.656,88 Pa memberikan perbedaan distribusi rata-rata tekanan paling rendah yaitu 101.333,21 Pa. Jumlah sudu dan sudut blade berpengaruh pada tekanan yang dihasilkan. Semakin bertambahnya sudu, maka tekanan semakin kecil. Dengan penambahan sudut blade pada tekanan mendapat hasil yang berbedabeda, pada turbin 2 sudu mengalami kenaikan tekanan di setiap sudutnya. Selanjutnya pada turbin 3 sudu mengalami fluktuasi tekanan di setiap sudutnya, sedangkan pada turbin 4 sudu mengalami penurunan tekanan di setiap sudutnya.

\section{REFERENSI}

[1] I. Mabrouki, Z. Driss and M. S. Abid, Experimental Investigation of the Height Effect of Water Savonius Rotors, International Journal of Mechanics and Applications, vol. 4, no. 1, 2014, pp. 8-12.

[2] N. Rosmin, A. S. Jauhari, A. H. Mustaamal, F. Husin and M. Y. Hassan, Experimental study for the single-stage and double-stage two-bladed Savonius micro-sized turbine for rain water harvestig (RWH) system, Energy Procedia, vol. 68, 2015, pp. 274-281.

[3] ESDM, Draft General Plan of Electricity (RUKN) $2012-$ 2031, 2013. Website: https://gatrik.esdm.go.id/assets/uploads/download_index/f iles/62781, diakses pada tanggal 07 Mei 2021

[4] T. Zhipeng, Y. Yingxue, Z. Liang and Y. Bowen, A review on the new structure of savonius wind turbines, Advanced Materials Research, vol. 608-609, 2013, pp. 467-478. 
[5] J. V. Akwa, H. A. Vielmo and A. P. Petry, A review on the performance of Savonius wind turbines", Renewable and Sustainable Energy Reviews, vol. 16, no. 5, 2012, pp. 3054-3064.

[6] K. A. Syahrul dan M. A. Sahbana, Pengaruh Jenis Sudu Terhadap Daya Dan Efisiensi Turbin Air Kinetik Poros Horizontal, vol. 10, no. 2, 2018, pp. 20-24.

[7] Z. Mao and W. Tian, Effect of the blade arc angle on the performance of a Savonius wind turbine, Advances in Mechanical Engineering, vol. 7, no. 5, 2015, pp. 1-10.

[8] A. Hakam, Simulasi Numerik Aliran Fluida Di Sekitar Dua Silinder Sirkuler Side-By-Side, Tesis, Institut Teknologi Sepuluh Nopember, Surabaya, 2015.

[9] S. Harahap dan H. Sasongko, Analisa Karakteristik Distribusi Tekanan dan Kecepatan Pada Bodi Aerodinamika Airfoil Dengan Metoda Panel Dalam Fenomena "Flow Around Body", Jurnal Teknik Mesin, vol. 5, no. 1, 2003, pp. 22-35.

[10] N. T. Hardhyanto, Studi Numerik Pengaruh Sudut Blade Terhadap Karakteristik Aliran Fluida Turbin Savonius Sumbu Vertikal Tipe-L, Tesis, Institut Teknologi Sepuluh Nopember, Surabaya, 2016.

[11] M. S. Arif, Margianto dan E. Marlina, Pengaruh Putaran Runner terhadap Daya Listrik yang Dihasilkan dengan Memvariasi Ukuran Nozzle pada Prototype Turbin Pelton, Jurnal Teknik Mesin, vol 5, no. 1, 2015, pp. 1-7.

[12] M. R. Yusuf, M. Hasbi dan Samhuddin, Analisa Pengaruh Variasi Tekanan dan Jarak Semprot Nozzle Terhadap Daya Output Pada Instalasi Turbin Pelton, Ilmiah Mahasiswa Teknik Mesin, vol. 4, no. 1, 2019, pp. 1-10.

[13] F. Aryanto, I. M. Mara dan M. Nuarsa, Pengaruh Kecepatan Angin dan Variasi Jumlah Sudu Terhadap Unjuk Kerja Turbin Angin Poros Horizontal, Dinamika Teknik Mesin, vol. 3, no. 1, 2013, pp. 50-59.

[14] Ridwan dan A. Latief, Pengaruh Jumlah Sudu Pada Turbin Angin Sumbu Vertikal Terhadap Distribusi Kecepatan Dan Tekanan, Jurnal Ilmiah Teknologi dan Rekayasa, vol. 24, no. 2, 2019, pp. 141-151. 